\title{
Casamentos em Consulados
}

\author{
João Arruda
}

Nas páginas 462 e 463 de sua preciosa obra "Direito Internacional Privado", critica o ilustre jurisconsulto pátrio o exmo. sr. ministro Esprnola minha opinião sôbre uma questão muito controvertida, qual a de saber se são os consules competentes para a celebração do casamento, quando um dos contraentes é súbdito ou cidadão do país onde se encontra o consulado. Sustentei a afirmativa, e o grande internacionalista, de acôrdo com o professor Villela, abraçou a solução negativa. Referiu-se o meu distinto contestante a uma nota que lancei em meu modesto livro "Do Casamento" para o pôr de acôrdo com o Código Civil, no momento em que foi este promulgado, em 1916.

Como tem sucedido aparecerem, em São Paulo, alguns casamentos de brasileiras com estrangeiros, e vice versa, sendo tais atos celebrados em consulados estrangeiros, pareceu-me que não deveria deixar de apresentar os motivos por que sustentei a tese impugnada pelo notavel internacionalista brasileiro. De dois casamentos dessa espécie tive notícia em meu escritório. Não fôra a responsabilidade que me cabe em tão grave assunto, e eu, desvanecido por ter meu livrinho chamado a atenção do douto civilista pátrio, nada. diria em contestação ao que deixou escrito contra minha opinião o sábio Juiz.

Sua argumentação que se resume em poucas linhas não me convenceu. Diz êle: "Na ausência de qualquer dispo- 
sição do Código sôbre a matéria, fôrça é recorrer ao princípio dominante no Direito anterior, o qual suprirá as lacunas da nova lei" No silencio da lei nova, sem dúvida deve o intérprete recorrer ao Direito anterior, á lei antiga, donde a regra corrente no fôro que diz que "correctoriae leges stricte sunt interpretandae" E' ela fundada no preceito do Digesto que diz: "Posteriores leges ad priores pertinent: nisi contrariae sint" (De Legibus, fr. 28). Mas surge uma exceção, que é apresentada por Dernburgo, e é a de ser a nova lei uma "codificação" Diz o mestre: "Un contraposto alle leggi correttorie costituiscono le cosidette "codificazioni". Esse prescrivono l'abolizione di tutte le leggi, che entrano nelle "materie" da loro regolate" (Tradução de Cicala, parágrafo 30. Pandette). A lição de Dernburgo é lei no Brasil, como se póde ver no artigo 1.807 do Codigo Civil, o qual deixou para a solução dos casos omissos em seu texto, não as leis anteriores, mas os principios gerais de Direito (artigo 7). Assim, nenhum motivo há para se ater o intérprete á letra do D. 181, sôbre o qual passou o Codigo Civil uma esponja.

Restam pois os princípios gerais do Direito anterior. Diz, com a costumada exatidão, o meu notavel antagonista: "Os Estados estrangeiros variam na determinação dos principios referentes ao casamento diplomático ou consular de seus nacionais na parte de que aqui nos ocupámos" (pag. 463). Qual pois o farol que deverá guiar o intérprete? $E^{\prime}$ certo que a convenção de Haya, no artigo 6, exige, para o casamento consular, que não seja nenhum dos contraentes nacional do lugar em que o casamento se houver celebrado. Mas se o codificador pátrio quisesse manter tal preceito da convenção, não teria sôbre o ponto guardado silêncio, não seria omisso sôbre êste requisito ou sôbre esta condição. A omissão pareceu-me um alargamento á faculdade concedida aos nubentes. E' o próprio emérito civilista pátrio que diz, em seu valioso livro, que assim era pela lei portuguesa, de 1911, assim é pelas leis da Alemanha, da Suecia, da França, da Dinamarca, da Belgica e da Italia (pg. 463). Por todos 
êstes sistemas legislativos, basta para a validade do casamento consular, que um dos contraentes seja cidadão do país representado pelo consul celebrante.

Feita a defesa de minha nota ao livrinho "Do Casamento", não deixarei a pena, sem algumas observações finais sôbre os casamentos já celebrados, e que são nulos no entender do emérito internacionalista o exmo. sr. ministro Espinola.

Uma é que, na dúvida, sempre deve ser julgado válido o casamento, como firmou Clovis em texto expresso de seu projeto (Gazeta Jurídica, 25|230, artigo 268), regra que não se acha formulada em termos positivos no Código Civil pátrio, mas que se infere de vários artigos dele.

A outra é que, segundo o mesmo ilustre civilista e internacionalista pátrio, infelizmente há povos que, dando a seus cônsules a atribuição de celebração de casamentos, não a concedem aos cônsules estrangeiros, o que é uma violação do princípio de "reciprocidade" que deve dominar as relações internacionais.

Enfim que, anulado um casamento consular celebrado em França pelo motivo que acaba de ser exposto, foi todavia, pelo Tribunal do Sena, julgado putativo, atendendo á bôa fé dos cônjuges, decisão de 1893 (Clovis, Dir. da Familia, parágrafo 20, i. f). Assim pois os casamentos celebrados por cônsules estrangeiros em nosso país, ainda quando seja um dos contraentes brasileiro, devem ser havidos como válidos em meu sentir; e, quando haja Juiz que entenda diversamente, ao menos como sendo putativos, devem darlhes ef eitos.

Quasi sempre os consulentes querem saber se houve já algum julgado, sobre o assunto em nosso país. Pela folha que anexei ultimamente ao meu modesto livro "Do Casamento", sob o título "O Casamento no Fôro Brasileiro" notei que o caso, até a data em que compulsei os varios re:pertórios de jurisprudência pátria, março de 1926, ainda não tinha ocupado a atenção do Poder Judiciário no Brasil. 
Uma última palavra que mostrará ter eu procurado apurar as modificações por que tem passado o Direito sôbre a matéria. Esta é que o recente Código de Direito Internacional Privado nos artigos 41 e 42 nenhuma alteração trouxe sôbre tão grave assunto (Rev. dos Tribs., 72/484).

Eis o que me ocorre dizer em matéria de conseqüências tão importantes para o sossêgo da familia no Brasil. 